\title{
Bentuk Origami Modular pada Struktur Lipat
}

\author{
Beta Suryokusumo $\mathbf{S}^{\mathbf{1}}$, Ary Deddy Putranto ${ }^{\mathbf{1}}$ dan Iwan Wibisana ${ }^{1}$ \\ 1 Jurusan Arsitektur/Fakultas Teknik/Universitas Brawijaya. \\ *uyoke3@gmail.com/bsudarmo@ub.ac.id
}

\begin{abstract}
ABSTRAK
Struktur lipat dapat menjadi salah alternatif untuk ruang dalam yang luas dan arsitektur bentang panjang. Melalui bentuk lipat, aspek kebutuhan ruang yang cukup besar dapat diwadahi. Inspirasi dari alam dan seni hasta karya dapat menjadi satu jalan untuk menciptakan konstruksi lipat. Salah satu seni lipat yang dikenal adalah origami. Bentuk origami modular diidentifikasi pada aspek rancangan, kekuatan dan aspek fungsi. Hasil eksplorasi memungkinkan untuk pengembangan stuktur lipat dengan teknik origami modular, baik secara permodelan maupun digital. Hasil kajian bertujuan untuk pengembangan teknik merancang konstruksi bentang panjang. Selain iu adalah pengembangan metode teknik dan eksplorasi bentuk seni lipat pada konstruksi lipat. Hasil kajian adalah temuan kriteria rancang konstruksi lipat dan model dasar yang dapat dikembangkan lagi melalui seni origami.
\end{abstract}

Kata kunci:seni origami, bentuk modular, struktur lipat

\begin{abstract}
Long-span architecture can be a consideration when we need a large interior and long span architecture. Thorugh the inspiration of nature and hand working, it can be one way to create folding construction. One of the reconzed hand arts is origami. Origami which deliberated to modular origami can be identified by design, firmness, and function. The result are developeing folded plate combine by modular origami techniques as a modelling and digital result. through origami, the finding result is origami provide a data base as design criterias and three model of basic folded plate
\end{abstract}

Keywords: the art of origami, modular shape, folded strucure

\section{Pendahuluan}

Kata "Origami" berasal dari bahasa Jepang, "Oru", yang berarti melipat dan "Kami" berarti kertas. Kata "kami" berubah menjadi gami, pada saat digabungkan, menjadi melipat kertas. Dalam perkembangannnya origami digunakan untuk hiasan berupa gantungan dan digunakan sebagai simbol keberuntungan. Bentuk-bentuk yang dihasilkan beragam dari bentuk binatang, tumbuhan atau bentuk geometris, tujuannya untuk menggambarkan sesuatu yang bermakna. Keindahan seni origami terdapat pada cara melipat-lipat kertas yang menghasilkan suatu bentuk mahluk hidup dan bentuk geometris. Selain itu juga menghasilkan bentuk abstrak atau bentuk matematikal. Perkembangan selanjutnya menjadi seni origami modular, di mana terjadi banyak pengulangan dari suatu lipatan yang sederhana yang dirangkai hingga membentuk struktur besar dengan komposisi yang menarik. Proses origami modular dan proses imajinasi diperlukan untuk menghasilkan bentuk-bentuk ruang yang diinginkan.

Dalam arsitektur melipat kertas melalui seni bentuk origami modular dapat membantu merangsang kepekaan persepsi dan intuisi seseorang terhadap bentuk dan 
kekokohan struktur. Dengan eksplorasi lipat dan manipulasi kertas, kedua tangan dan mata bekerja sama secara langsung untuk memahami berbagai bentuk yang dapat dihasilkan. Friederich Froebel (1850) menggunakan kertas lipat pada anak usia dini di taman kanak-kanak untuk melatih pemahaman geometri dan kepekaan rasa estetika matanya. Kemudian Joseph Albers (1950) menggunakan metoda seni melipat kertas serupa pada kelas preparasi arsitektur di Bauhaus untuk memberikan pemahaman kepada mahasiswanya hubungan antara material (bahan), bentuk geometri, dan struktur.

Untuk itu permasalahan yang hendak dijawab dalam penelitian ini adalah bagaimanakah konsep seni bentuk origami modular pada struktur lipat? Permasalahan akan dijawab melalui upaya mengidentifikasi konsep-konsep pola origami yang dapat ditemukan.

\section{Bahan dan Metode}

\subsection{Pola origami}

Konsep origami telah di publikasikan Krier (2007), "Mathematics and Origami: Ancient Arts Unite", mengenai hubungan origami dengan matematik. Dengan origami dapat dijelaskan konsep matematika sebagai sebuah geometri secara mudah dicerna. Bentuk lipatan dari origami dapat menjelaskan mengenai konsep kuadratik dan perhitungan kubik. Kajian yang dipublikasikan oleh Trautz (2008), "Deployable folded plate structures-folding patterns based on 4-fold mechanism using stiff plates". Pada kajian ini dijelaskan mekasnisme empat lipatan, yang disebut dengan pola "Miura-Ori". Polapola matematika dapat dijelaskan melalui model kertas melalui pola lipatan. Kemungkinan kombinasi lain adalah mekanisme lipatan tunggal empat sisi menjadi pola yang besar yang dapat di kembangkan. Kajian yang sejenis dilakukan oleh Trautz dan Cherniak (2008) berjudul "Folds and fold Plate Structure in Architecture and Engineering". Tujuan dari penelitian ini adalah melihat origami dari metode morfologi struktur untuk meningkat kapasitas pembebanan pada seni dasar dan teknik rekayasa.

Buri (2008), dalam “Origami Folded Plate Structures, Architectures”, menerapkan metode baru dalam menerapkan secara cepat bentuk struktur lipat yang dapat di bangun dengan panel kayu laminasi. Tujuan dari riset ini adalah kajian multi disiplin baik dari sisi arsitektural, struktural, dan aspek matematika dengan model, struktur lipat yang dibentuk dari panel laminasi kayu. Penelitian yang dilakukan oleh Sze (2005), "Constructivism and The Ancient Art of Origami", adalah membuat kerangka kerja pemikiran mengenai konstruksi origami dan pola konstruksi yang digali secara konsepsual dan kerangka teori yang berhubungan langsung pembelajaran secara konstruktif, "Constructive Learning". Kemudian kajian yang dilakukan oleh Matsubara (2004), "Origami: Symetry and Aplication in Architecture", yang menstudi secara geometri dari bentuk simetri origami, terutama pada arsitektur dan seni dekoratif dimana origami dapat dikategorikan melalui aspek kesimetrian. Penelitian yang dilakukan oleh Ida dan Marin (2008), "Computanional Origami Constructuction as Constraint Solving and Rewriting", menjelaskan mengenai origami dari sisi metode melipat yang disebut metode Hutzita's Axiom System. Kajian yang dilakukan Gibson (2007), "Investigation of Multi FoldedPlate Structure", mengenai perilaku dari struktur lipat. Disamping itu adalah adalah melihat kemungkinan bahwa struktur lipat merupakan struktur yang mudah dan murah untuk menghasilkan rancangan bentang panjang.

\subsection{Teknik origami dalam Arsitektur}


Teknik dasar origami adalah melipat. Lipatan sederhana adalah lipatan "valley" (lembah), dimana sepotong kertas rata dilipat dengan ciri jika dikembalikan lagi (tidak dilipat lagi) garis lipatan akan membentuk suatu sungai/ lembah. Lipatan dasar lainnya adalah lipatan mountain (gunung), dimana jika kertas dikembalikan lagi akan membentuk suatu bubungan yang terangkat atau bentukan gunung. Lipatan "mountain" (gunung) ini jelas kontras dengan lipatan "valley". Kombinasi-kombinasi dari lipatanlipatan dasar ini dapat membentuk dasar permulaan bentuk yang dapat digunakan untuk melipat berbagai model dari yang sederhana menjadi model yang rumit. Modular origami terdiri dari menempatkan sejumlah potongan-potongan serupa bersama untuk membentuk sebuah model yang lengkap.

\section{Teknik Melipat}

Melipat dalam arsitektur memiliki makna yang lebih mendalam dan rumit daripada hanya sekedar mengucapkan istilah "folding" ataupun mencoba membuat lipatan dari kertas. "Folding" dapat berupa sebuah atau serangkaian perlakuan pada sebuah benda (biasanya kertas) yang mengakibatkan perubahan bentuk, permukaan, makna pada benda tersebut. Biasanya perlakuan yang diberikan pada sebuah kertas dalam rangka mem-"folding" kertas tersebut adalah "fold, pleat, crease, press, score, cut, pull up, pull down, rotate, twist, turn, wrap, enfold, pierce, hing, knot, weave, compress, balance, unfold". Beberapa dari kata tersebut sama-sama memiliki arti 'lipat' dalam kamus Inggris-Indonesia namun sebenarnya 'lipat' yang dimaksud adalah cara 'lipat' yang berbeda. Berbeda dengan origami, dua buah proses "folding" bisa saja memiliki tahap yang sama, tetapi menghasilkan bentuk yang berbeda. Hal ini terjadi karena proses dalam "folding" tidak memiliki aturan tertentu dalam mengerjakannya. Misalnya, "fold": bisa berarti melipat di tengah-tengah kertas, atau melipat di ujungnya saja, atau melipat di seperempat bagian kertas, dan sebagainya. Kesimpulan sementara adalah origami bisa jadi termasuk bagian dari "folding", bagian yang lebih terdefinisi.

\section{Pola Lipatan}

Melipat kertas dapat membantu merangsang kepekaan persepsi dan intuisi terhadap bentuk dan kekokohan folded plate structures. Dengan eksplorasi lipat dan manipulasi kertas, kedua tangan dan mata bekerja sama secara langsung untuk memahami berbagai bentuk yang dapat dihasilkan. Kertas lipat diajarkan di taman kanak-kanak untuk melatih pemahaman geometri dan kepekaan rasa estetika matanya. Terdapat beberapa teori mengenai struktur lipat berdasar teori Origami, yakni: terdapat tiga pola teridentifikasi dapat diaplikasikan pada bentuk arsitektural dan aplikasi struktural: pola Yoshimura, pola Miura Ori, dan pola Diagonal. Ketiganya adalah kombinasi dari accordion folding (lipatan lembah-bukit) dan reverse fold (lipatan terbalik): sejumlah bentukan lembah dan bukit dari lipatan ditekuk menggunakan lipatan kebalikan untuk menghasilkan sebuah permukaan lengkung sederhana. Reverse fold adalah salah satu teknik dasar dari origami: sebuah lipatan pararel dapat ditekuk melalui lipatan diagonal yang memotong melintang persis pada lipatan pararel tersebut.

Pola Yoshimura (Pola Berlian/Diamond). Dasar dari pola ini adalah pola lipatan yang serupa diamond yang dihasilkan pada salah diagonalnya. Pola ini dapat dihasilkan melalui sebuah bidang silinder tipis yang dimampatkan menurut sumbu porosnya. Pola Diagonal; dasar dari pola ini berupa lipatan berbentuk jajar genjang pada diagonalnya. Pola tekukan serupa dapat terlihat pada sebuah bidang tipis silinder dimampatkan (ditekan) dengan sebuah distorsi (puntir). Pola Miura Ori (Pola Herringbone). Seperti pada pola diamond, pola ini juga terbentuk oleh susunan "reverse fold" yang berulang. Pada pola ini, bentukan "reverse fold" dicerminkan dan diulang disusun segaris sehingga membentuk pola garis zigzag dalam dua arah. Sehingga memungkinkan untuk mengembang dan merapat pada dua arah tersebut. "Parallel Corrugation" (Gelombang 
Berjajar); Bentukan dasar ini serupa bentukan bergelombang bukit dan lembah. Bentuk ini dapat digambarkan dengan susunan garis zigzag sepanjang garis lurus. Garis zigzag dapat dikarakteristikkan menurut tekanan dan amplitude dari setiap segmennya. Semakin tinggi amplitude-nya, semakin kuat daya tahan lipatnya terhadap tekanan. Tatanan bukit-lembah juga berperan dalam menentukan kekuatan lipat.

"Reverse Fold" (Lipatan Terbalik). Lipatan terbalik dapat digambarkan dengan sebuah lipatan sejajar (paralel) pada sebuah bidang horizontal. Jumlah kemungkinan hubungan lipatan antara lipatan paralel utama berupa bidang horizontal yang tegak lurus terhadap sudut garis bagi dari dua lipatan sejajar utama. Lipatan tambahan (lipatan pertemuan lipatan utama) berada pada bidang horizontal ini. Garis dari lipatan utama dan sisi sampingnya sejajar dan tercermin pada garis tegak lurus terhadap sudut garis baginya. Dengan bantuan teknik digital, dibutuhkan dua garis untuk mengidentifikasi struktur lipat:

1. Yaitu berupa garis poligonal pembentuk utama pada sisi potongan. Dimana titik awal bentuk lipat yang berupa akordion mengikuti garis dan terbalik pada setiap titik tekukan.

2. Garis poligonal sekunder pembentuk gelombang pada titik lipat akordion, garis ini mendefinisikan lipatan-lipatan sejajar.

\subsection{Metode Penelitian}

Penelitian ini menurut Darjosanjoto (2006); Moleong, (2002), menggunakan metode kualitatif dengan pendekatan deskriptif. Suharsimi (2010) sifat deskriptif bertujuan untuk meyelidiki keadaan, kondisi, situasi, dan lainnya yang dipaparkan dalam bentuk laporan penelitian. Kajian yang dilakukan adalah dengan mendeskripsikan obyek melalui proses analisis dan sintesis yang kemudian ditarik sebuah kesimpulan atas hasil penelitian tersebut. Kajian kualitatif digunakan untuk mengidentifikasi tingkat hubungan antara variabel-variabel melalui hubungan sejajar.

Langkah-langkah penelitian adalah sebagai berikut:

1. Rancangan penelitian yang digunakan dalam kegiatan ini adalah mengidentifikasi desain origami dan struktur lipat melalui studi literatur baik dari sumber bacaan, media web, publikasi ilmiah dan penelitian yang sejenis.

2. Observasi data sekunder melalui literatur yang berhubungan dengan fokus kajian seni origami, bentuk origami modular dan struktur lipat.

3. Memetakan pola-pola dari bentuk origami dan struktur lipat dalam rancangan tabulasi sederhana.

4. Penyusunan data baik secara teoritis dan grafis menjadi dasar untuk melakukan kategorisasi berdasarkan bentuk, rupa, kekuatan dan pola rancangan yang ada.

5. Menentukan kriteria berupa variabel-variabel analisis berdasarkan aspek-aspek pola pola bentuk pada obyek penelitian.

6. Identifikasi unsur-unsur arsitektural pada obyek penelitian sebagai validasi sebelum dilakukan proses analisis berdasarkan penetapan variabel berdasarkan aspek desain origami dan aspek desain struktur lipat (folded plate). Juga terdapat proses mendeskripsikan dan mengeksplorasi berdasarkan aspek tinjaun desain (style), konstruksi (firminitas), function (fungsi) pada sumber data yang ada.

7. Analisis dapat dilakukan dengan evaluasi pada bentuk-bentuk yang dapat diaplikasikan dalam sistem struktur dan konstruksi.

8. Pembuatan desain dwimatra dilakukan melalaui metode sketsa dan digitaliasi, agar dapat diperoleh bentuk dari struktur dan konstruksi lipat.

9. Analisis dilakukan untuk memperoleh berbagai aspek desain dan model yang dapat diterapkan secara aplikatif dan dapat digunakan oleh pengguna sebagai bagian dari 
penutup suatu bangunan atau juga dapat merupakan kulit yang menutupi bangunan baik secara estetika maupun struktural

\section{Pembahasan}

Dalam pembahasan ini pola origami modular dan struktur lipat dapat di identifikasi berdasarkan pola perilaku struktur lipatan, perilaku gaya tekuk, proses bentuk, jenis bahan yang digunakan, teknik lipatan dan analisa geometri lipatan.

\section{Analisis perilaku struktur lipatan}

Secara kualitatif perilaku struktur lipat dapat berupa cangkang yang datar yang dapat dibentuk (dikembangkan), di mana perilakunya akan semakin berbeda dengan semakin panjang relatifnya. Terdapat dua tipe yaitu "short folded plates", dan "long folded plate". Short folded plate mempunyai tiga tipe: sebagai sebuah "slabs" yang membentang diantara tiga tumpuan, kedua; sebagai sebuah serial dari tiga tumpuan yang dijejer berseberangan, dan ketiga; menjadi sebuah atap gable dengan tumpuan menerus. "Long folded plate", mempunyai satu tipe dimana penyaluran beban yang mempunyai titik tekan diatas dan titik regangan di sisi bawah.

\section{Tabel 1. Perilaku Beberapa Tipe Struktur Lipat}

\begin{tabular}{|c|c|c|c|c|}
\hline No & Tipe & Arah gaya & Tumpuan & Kesimpulan \\
\hline 1 & $\begin{array}{l}\text { Bidang lipat slabs } \\
\text { pada tumpuan } \\
\text { rangka segitiga }\end{array}$ & $\begin{array}{l}\text { Mendatar } \\
\text { (horizontal } \\
\text { sepanjang } \\
\text { batang }\end{array}$ & $\begin{array}{l}\text { Pada tititk titik } \\
\text { kolom }\end{array}$ & $\begin{array}{l}\text { Penyaluran beban lebih diarahkan pada } \\
\text { tumpuan kolom. Tidak perlu } \\
\text { menggunakan pembalokan karena } \\
\text { slabberfungsi sebagai bidang horisontal }\end{array}$ \\
\hline 2 & $\begin{array}{l}\text { Rangkaian sejenis } \\
\text { yang bersisian } \\
\text { dengan tumpuan } \\
\text { rangka segitiga }\end{array}$ & $\begin{array}{l}\text { Penyebaran } \\
\text { gaya } \\
\text { vertikal }\end{array}$ & $\begin{array}{l}\text { Diletakkan } \\
\text { batang } \\
\text { memanjang } \\
\text { berfungsi sebagai } \\
\text { balok penerus } \\
\text { beban }\end{array}$ & $\begin{array}{l}\text { Penyaluran beban } \\
\text { vertical sepanjang garis gaya melalui } \\
\text { batang melintang } \\
\text { kolom }\end{array}$ \\
\hline 3 & $\begin{array}{l}\text { Jenis atap gable } \\
\text { yang di tunjang } \\
\text { oleh dinding } \\
\text { pemikul; }\end{array}$ & $\begin{array}{l}\text { Penyaluran } \\
\text { beban } \\
\text { secara } \\
\text { vertical }\end{array}$ & \begin{tabular}{lr}
\multicolumn{2}{l}{ Diletakkan } \\
bidang dinding \\
slabs & sepanjang \\
garis & gaya \\
vertikal & \\
\end{tabular} & $\begin{array}{l}\text { Penyaluran beban diarahkan secara } \\
\text { vertical dan disebarkan secara menerus } \\
\text { pada bidang dinding slabs secara vertical } \\
\text { kedalam tanah. }\end{array}$ \\
\hline 4 & $\begin{array}{l}\text { Jenis bidang lipat } \\
\text { yang ditunjang } \\
\text { pada tumpuan } \\
\text { kolom dan } \\
\text { bentang panjang }\end{array}$ & $\begin{array}{l}\text { Penyaluran } \\
\text { gaya tekan } \\
\text { pada titik } \\
\text { buhul dan } \\
\text { regangan } \\
\text { pada sis } \\
\text { bawah }\end{array}$ & $\begin{array}{ll}\text { Pada titik } & \text { kolom } \\
\text { dengan } & \text { secara } \\
\text { horisontal } & \end{array}$ & $\begin{array}{l}\text { Bidang lipat bentang panjang akan } \\
\text { menyalurkan beban horisontal secara } \\
\text { merata ke tumpuan. Kemampuan akan } \\
\text { bertambah bila rasio panjang dan lebar } \\
2: 1 \text {. }\end{array}$ \\
\hline
\end{tabular}



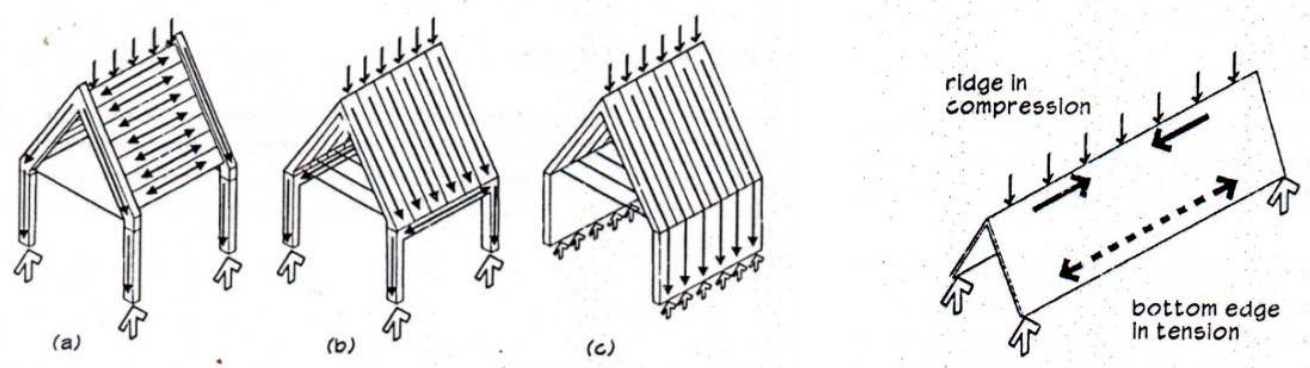

Gambar 1. Perilaku Tegangan dan Regangan dalam Pola Lipatan

\section{Analisis perilaku gaya tekuk}

Gaya tekuk dipengaruhi oleh rasio lebar dan panjang dari struktur lipat tersebut. Menghindari gaya tekuk adalah memperkuat garis potong sepanjang tepi dari bidang tersebut, dengan memperkuat pada tumpuan penyaluran beban gaya ke dalam tanah. Tiga tipe perkuatan tersebut adalah:

Tabel 2. Jenis Perkuatan Struktur Lipat untuk Menghindari Gaya Tekuk

\begin{tabular}{|l|l|l|l|l|}
\hline No & Jenis / Tipe & \multicolumn{1}{|c|}{ Tumpuan } & $\begin{array}{l}\text { Jenis perkuatan untuk } \\
\text { menghindari gaya } \\
\text { tekuk }\end{array}$ & \multicolumn{1}{|c|}{ Kesimpulan } \\
\hline 1 & $\begin{array}{l}\text { End support for } \\
\text { multi bay folded } \\
\text { plate }\end{array}$ & $\begin{array}{l}\text { Pada tepi / ujung } \\
\text { dari kolom }\end{array}$ & $\begin{array}{l}\text { Membuat perkuatan } \\
\text { pada rangka segitiga } \\
\text { dengan ikatan } \\
\text { mendatar untuk } \\
\text { mengurangi gaya } \\
\text { mendatar }\end{array}$ & $\begin{array}{l}\text { Jenis perkuatan gaya dengan } \\
\text { pembanan setempat, } \\
\text { dimana gaya disalurkan } \\
\text { pada tepi rangka segitiga } \\
\text { dan kolom, dengan ikatan } \\
\text { angin untuk mencegah gaya } \\
\text { mendatar }\end{array}$ \\
\hline 2 & $\begin{array}{l}\text { End bearing wall } \\
\text { support for multi } \\
\text { bay folded plate }\end{array}$ & $\begin{array}{l}\text { Dengan dinding } \\
\text { pemikul akhir (end } \\
\text { bearing wall) }\end{array}$ & $\begin{array}{l}\text { Membuat perkuatan } \\
\text { dengan dinding } \\
\text { pemikul yang } \\
\text { disebarkan sepanjang } \\
\text { garis gaya di pondasi }\end{array}$ & $\begin{array}{l}\text { Jenis perkuatan dengan } \\
\text { pembebanan merata, pada } \\
\text { dinding pemikul, juga } \\
\text { berfungsi menjadi penahan } \\
\text { gaya geser }\end{array}$ \\
\hline 3 & $\begin{array}{l}\text { Outer shell edges } \\
\text { support for multi } \\
\text { bay folded plate }\end{array}$ & $\begin{array}{l}\text { Pada kolom } \\
\text { berbentuk Y } \\
\text { shapess }\end{array}$ & $\begin{array}{l}\text { Perkuatan dengan } \\
\text { penguat yang terbuat } \\
\text { dari kolom Y shapes } \\
\text { sebagai stiffers. }\end{array}$ & $\begin{array}{l}\text { Pembebanan di salurkan } \\
\text { sepanjang bidang lipat, } \\
\text { diperkuat dengan bentuk Y } \\
\text { shapes sebagai penyaluran } \\
\text { beban ke kolom }\end{array}$ \\
\hline
\end{tabular}



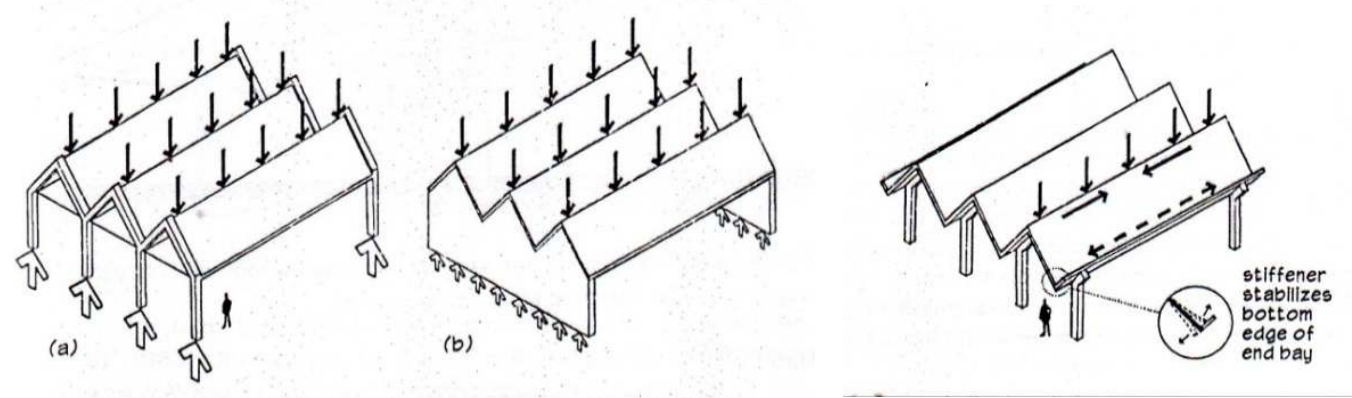

Gambar 2. Model End Support untuk Bidang Banyak Struktur Lipat

\section{Analisis bentuk}

Bentuk dapat dipengaruhi dengan perilaku gaya yang bekerja, rasio bentang panjang akan dipengaruhi oleh lebar bidang. Dengan membagi lebar bidang menjadi beberapa bagian yang sama akan mengurangi gaya tekan dan regangan yang terjadi pada tepian bidang tersebut. Melipat adalah mengurangi gaya tekan dan gaya regang dan memperkecil dimensi tebal bidang. Akibatnya gaya tekan dan regang dapat dikurangi pada tepian bidang. Hal lain menimbulkan konsekuensi bidang lipat menjadi semakin banyak pada daerah yang di tutupinya.

Tabel 3. Jenis Bentuk Struktur Lipat Akibat Gaya yang Bekerja

\begin{tabular}{|l|l|l|l|}
\hline No & \multicolumn{1}{|c|}{ Jenis Bidang } & \multicolumn{1}{|c|}{ Bentuk dasar } & Bentuk yang dihasilkan \\
\hline 1 & Bidang lipat sejajar & Bentuk prismatis & Bentuk melebar dan meluas \\
\hline 2 & $\begin{array}{l}\text { Bidang lipat sejajar berlawanan } \\
\text { puncaknya }\end{array}$ & Bentuk prismatis & Bentuk melebar dan meluas \\
\hline 3 & $\begin{array}{l}\text { Bidang lipat sejajar dengan } \\
\text { puncak ditengahnya }\end{array}$ & Bentuk prismatis & Bentuk melebar dan meluas \\
\hline 4 & $\begin{array}{l}\text { Bidang lipat membentuk } \\
\text { lingkaran }\end{array}$ & Bentuk dasar piramid & $\begin{array}{l}\text { Bentuk lingkaran/ } \\
\text { lengkungan }\end{array}$ \\
\hline 5 & Rangka bidang lipat menerus & Bentuk prismatis & Bentuk melebar dan meluas \\
\hline 6 & $\begin{array}{l}\text { Rangka bidang lipat dua sendi } \\
\text { two hinged) }\end{array}$ & Bentuk prismatis & Bentuk melebar dan meluas \\
\hline 7 & $\begin{array}{l}\text { Rangka bidang lipat tiga sendi } \\
\text { three hinged) }\end{array}$ & Bentuk prismatis & Bentuk melebar dan meluas \\
\hline 8 & $\begin{array}{l}\text { Permukaan lipat bidang } \\
\text { membentuk segitiga }\end{array}$ & Bentuk prismatis & Bentuk ruang segitiga \\
\hline 9 & $\begin{array}{l}\text { Permukaan lipat bidang } \\
\text { membentuk ruang segi empat }\end{array}$ & $\begin{array}{l}\text { Permukaan lipat bidang } \\
\text { membentuk ruang piramida }\end{array}$ & Bentuk piramida \\
\hline 11 & $\begin{array}{l}\text { Permukaan lipat bidang } \\
\text { membentuk ruang polyhedral }\end{array}$ & Bentuk piramida banyak & Ruang polyhedral \\
\hline
\end{tabular}

\section{Analisis bahan}


Bahan yang dapat digunakan untuk struktur lipat adalah seperti yang dijabarkan dalam tabel berikut ini:

Tabel 4. Jenis Bahan Struktur Lipat

\begin{tabular}{|c|c|c|c|c|c|}
\hline No & Jenis Bahan & Aplikasi & Kekuatan Struktur & Keunggulan & Kekurangan \\
\hline 1 & Paper (Kertas) & $\begin{array}{l}\text { Bahan berupa } \\
\text { papan kertas } \\
\text { laminasi }\end{array}$ & $\begin{array}{l}\text { Kekuatan struktur } \\
\text { tergantung dari } \\
\text { jumlah lembar } \\
\text { pada papan kertas } \\
\text { laminasi tersebut }\end{array}$ & $\begin{array}{l}\text { Baik untuk } \\
\text { permodelan }\end{array}$ & $\begin{array}{l}\text { Keterbatasan } \\
\text { bentang dalam } \\
\text { skala ruang dan } \\
\text { manusia }\end{array}$ \\
\hline 2 & $\begin{array}{l}\text { Plywood folded } \\
\text { plate }\end{array}$ & $\begin{array}{l}\text { Bahan berupa } \\
\text { lapisan kayu } \\
\text { yang di press } \\
\text { dengan } \\
\text { ketebalan } \\
0,125 \text { inch }\end{array}$ & $\begin{array}{l}\text { Kekuatan terletak } \\
\text { pada system } \\
\text { perkuatan yang } \\
\text { menggunakan } \\
\text { bahan perekat }\end{array}$ & $\begin{array}{l}\text { Dapat diterapkan } \\
\text { menjadi ruang atau } \\
\text { permodelan } \\
\text { dengan skala } \\
\text { sessungguhnya }\end{array}$ & $\begin{array}{l}\text { Keterbatasan } \\
\text { bentang panjang } \\
\text { bila kebutuhan } \\
\text { ruang besar } \\
\text { diperlukan } \\
\text { beberapa } \\
\text { tumpuan aau } \\
\text { perkuatan }\end{array}$ \\
\hline 3 & $\begin{array}{l}\text { Plastic coated } \\
\text { cardboard }\end{array}$ & $\begin{array}{l}\text { Bahan PVC } \\
\text { dengan } \\
\text { ketebalan } 1 \\
\text { inch hingga } \\
\text { dua inch }\end{array}$ & $\begin{array}{l}\text { Kekuatan terletak } \\
\text { pada kepadatan } \\
\text { dari jenis bahan } \\
\text { palstik tersebut }\end{array}$ & $\begin{array}{l}\text { Flexible dalam } \\
\text { penerapan, dapt } \\
\text { digunakan sebagai } \\
\text { kulit yang } \\
\text { ditunjang oleh } \\
\text { tumpuan dan } \\
\text { perkuatan }\end{array}$ & $\begin{array}{l}\text { Kemampaun PVC } \\
\text { dalam gaya tekan } \\
\text { menyebabkan } \\
\text { penggunaan } \\
\text { terbatas pada } \\
\text { permukaan } \\
\text { bidang }\end{array}$ \\
\hline 4 & Concrete beton & $\begin{array}{lr}\text { Bahan } & \text { dasar } \\
\text { pasir } & \text { dan } \\
\text { semen } & \end{array}$ & $\begin{array}{l}\text { Kekuatan tekan } \\
\text { dapat digunakan } \\
\text { untuk membuat } \\
\text { bidang-bidang } \\
\text { pararel dan } \\
\text { diagonal fold }\end{array}$ & $\begin{array}{l}\text { Pemukaan bidang } \\
\text { dapat lebih tipis } \\
\text { dengan } \\
\text { penggunaan } \\
\text { sttruktur fold ini, } \\
\text { perulangan bentuk } \\
\text { dapat lebih } \\
\text { ekonomis pada } \\
\text { pelaksanaannya }\end{array}$ & $\begin{array}{l}\text { Keterbatasan } \\
\text { bentuk lebih } \\
\text { kepada } \\
\text { Corrugated, } \\
\text { parrarel fold }\end{array}$ \\
\hline 5 & Baja & besi & $\begin{array}{l}\text { Kekuatan terletak } \\
\text { pada batang tarik } \\
\text { yang dapat } \\
\text { digunakan untuk } \\
\text { pembalokan }\end{array}$ & $\begin{array}{l}\text { Dapat } \\
\text { dikombinasikan } \\
\text { dengan material } \\
\text { lain sebagai } \\
\text { tumpuan dan } \\
\text { pembalokan }\end{array}$ & $\begin{array}{l}\text { Karakter batang } \\
\text { tarik dan jenis } \\
\text { material yang } \\
\text { rigid membuat } \\
\text { keterbatasanpada } \\
\text { aplikasi bidang } \\
\end{array}$ \\
\hline 6 & zincalume & $\begin{array}{l}\text { Campuran seng } \\
\text { dan } \\
\text { alumunium }\end{array}$ & $\begin{array}{l}\text { Kekuatan pada } \\
\text { lembaran yang } \\
\text { dapat di tekuk pada } \\
\text { dua arah }\end{array}$ & $\begin{array}{l}\text { Dapat di bentuk } \\
\text { dalam dua arah } \\
\text { gaya (bidang } \\
\text { melingkar }\end{array}$ & $\begin{array}{l}\text { Keterbatasan } 4 \\
\text { arah gaya tekuk }\end{array}$ \\
\hline
\end{tabular}

\section{Analisis teknik melipat}

Beberapa teknik melipat dari struktur lipat dapat di definisikan seperti pada tabel berikut:

Tabel 5. Teknik Lipatan pada Struktur Lipat

\begin{tabular}{|l|l|l|l|}
\hline No & \multicolumn{1}{|c|}{ Tipe } & \multicolumn{1}{c|}{ Teknik lipatan } & $\begin{array}{c}\text { Kesimpulan } \\
\text { Hasil bentukan }\end{array}$ \\
\hline 1 & $\begin{array}{l}\text { Folded plate panel } \\
\text { shapes }\end{array}$ & Pararel & $\begin{array}{l}\text { Bidang datar } \\
\text { pararel }\end{array}$ \\
\hline
\end{tabular}




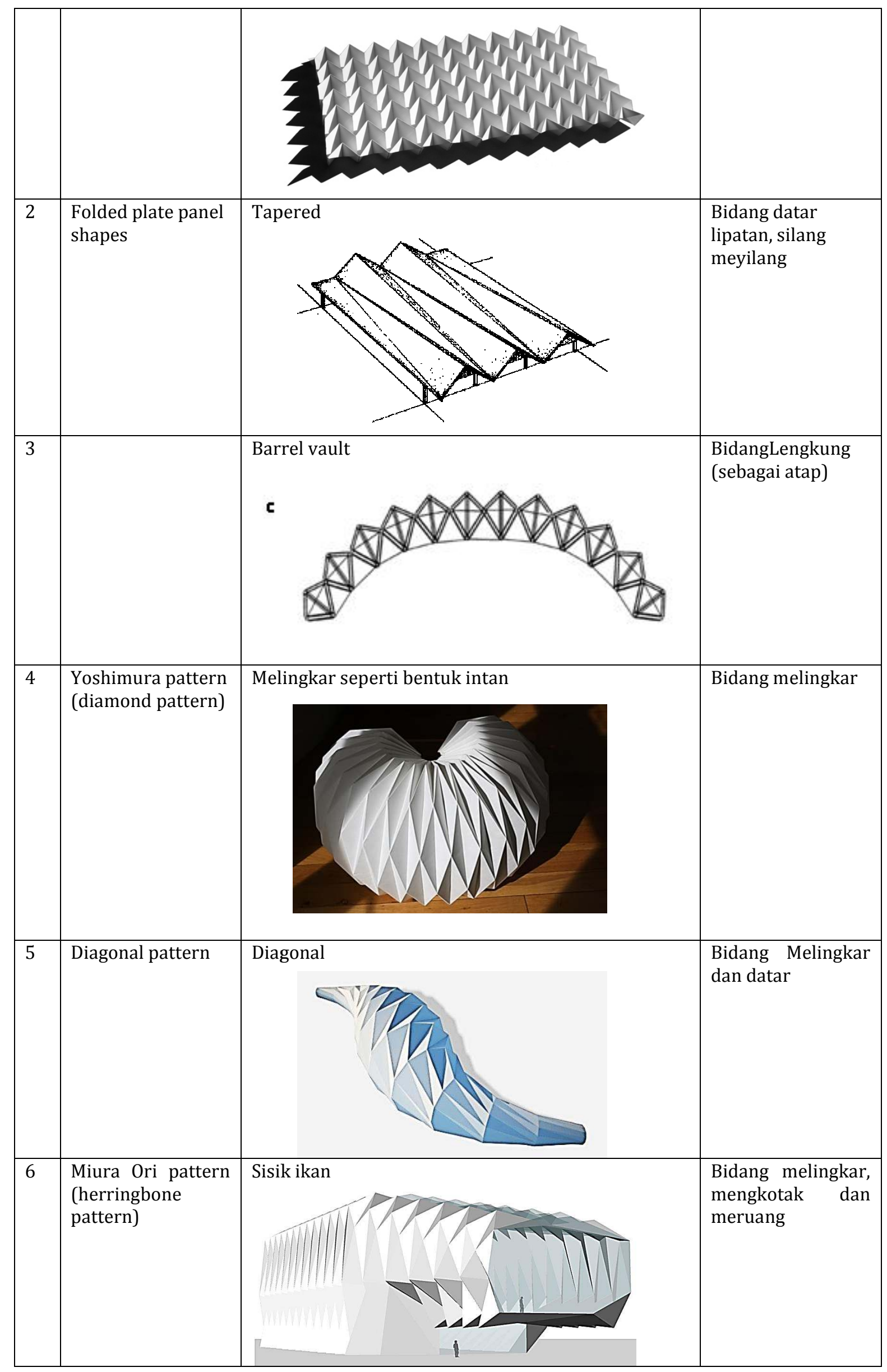




\section{Analisis geometri lipatan}

Tabel 6. Bentuk Dasar (Geometri) pada Struktur Lipat

\begin{tabular}{|l|l|l|l|}
\hline No & Teknik dasar melipat & Hasil bentuk & Kesimpulan \\
\hline 1 & $\begin{array}{l}\text { geometri lipatan } \\
\text { pararel corrugation }\end{array}$ & $\begin{array}{l}\text { Bentuk dasar yang mempunyai puncak } \\
\text { dan lembah, dengan arah silang } \\
\text { menyilang, menhasilkan lipatan yang } \\
\text { sejajar. Aplikasi bentuk lain adaalh } \\
\text { membentek seperti sebuah gelombang } \\
\text { yang semakin besar gelombang tsb, } \\
\text { berpengaruh terhadap semakin kua } \\
\text { rancangan struktur lipat tsb }\end{array}$ \\
\hline 2 & $\begin{array}{l}\text { geometri lipatan } \\
\text { Reverse fold two } \\
\text { dimensional reverse } \\
\text { fold) }\end{array}$ & $\begin{array}{l}\text { Bentuk lipatan terbalik, berupa sisik } \\
\text { ikan akibat perulangan lipatan yang } \\
\text { membentuk sebuah lingkaran seperti } \\
\text { intan, cirinya adalah zig zag corrugation } \\
\text { dalam dua arah, atau bentuk lipatan } \\
\text { silang meyilang dalam dua arah }\end{array}$ \\
\hline
\end{tabular}

\section{Kesimpulan}

Dari hasil kajian dapat disimpulkan: pola origami dan struktur lipat mempunyai kesamaan di dalam beberapa aspek seperti:

1. Mengolah suatu bidang menjadi bentuk tertentu.

2. Pengolahan bidang menjadi bentuk tertentu di dalam arsitektur sebagai pemanfaatan memperoleh ruang yang dapat digunakan oleh manusia.

3. Pengolahan bidang mempunyai teknik-teknik tertentu seperti teknik melipat, arah melipat dan pola melipat.

4. Beberapa jenis dan teknik melipat adalah untuk menciptakan ruang dan bentuk secara arsitektural. Struktur lipat dan seni origami dapat ditelusuri dari sistem perilaku gaya yang bekerja, pola-pola dan bentuk, teknik melipat, jenis bahan yang digunakan.

5. Pola origami modular dan struktur lipat dapat di identifikasi berdasarkan pola perilaku struktur lipatan, perilaku gaya tekuk, proses bentuk, jenis bahan yang digunakan, teknik lipatan dan analisis geometri lipatan.

Saran

1. Langkah lanjut dari kajian ini adalah memetakan pola-pola origami yang dapat diterapkan dalam dunia arsitektur dengan menggunakan referensi struktur lipat.

2. Memetakan pola struktur lipat dan studi bentuk dasar dengan permodelan. 
3. Membuat basis data berdasarkan evaluasi awal yang dapat digunakan untuk pengembangan struktur lipat dan seni origami dalam dunia arsitektur.

\section{Ucapan terima Kasih:}

Ucapan terima kasih kami sampaikan kepada:

1. Fakultas Teknik Universitas Brawijaya dan BPP FT-UB yang telah memfasilitasi kegiatan penelitian ini.

2. Jurusan Arsitektur FT-UB.

\section{Daftar Pustaka}

Arikuntono, Suharsimi. (2010). Prosedur Penelitian, Suatu Pendekatan Praktik. Jakarta: Penerbit Rinea Cipta.

Buri, H. (2008). Origami Folded Plate Structures, Architecture. WCTE 2008 Proceedings. Darjosajoto, Endang Titi Sunarti. (2006). Penelitian Arsitektur Bidang Perumahan \& Permukiman. Surabaya: ITS Press.

Gibson, J.E. (2007). Investigation of Multi Folded Plate Structure.

Ida, Tetsui, \& Marin, Mirca. (2008). Computanional Origami Constructuction as Constraint Solving and Rewriting.

Krier. Jaema. L. (2007). Mathematics and Origami: Ancient Arts Unite.

Matsubara, Juliana. (2004). Origami: Symetry and Aplication in Architecture.

Moleong. Lexy J. (2002). Metodologi Penelitian Kualitatif. Bandung: Remaja Rosdakarya.

Sze, Susan. (2005). Constructivism and The Ancient Art of Origami. Niagara University: Innovations in Inclusive School Development, Conference Proceedings.

Trautz, Martin, \& Kunstler, Arne. (2008). Deployable Folded Plate Structures-folding Patterns Based on 4-fold Mechanism Using Stiff Plates. University of Georgia.

Trauz, Martin, \& Cherniak, Susanne. (2008). Folds and Fold Plate Structure in Architecture and Engineering. University of Georgia.

Wingler, Hans M. (1969). Paper Study Albers, Josef at Bauhaus: Weimar, Dessau, Berlin, Chicago. MIT Press.

Yordanka, Valkanova, \& Kevin, J. Brehony. (2006). Special Issue: Early Years Education: Some Froebelian Contributions; History of Education. Journal of the History of Education Society Volume 35. 